American Journal of Applied Sciences 5 (1): 18-21, 2007

ISSN 1546-9239

(C) 2007 Science Publications

\title{
Use of Capital Budgeting Methods for Investment Project Evaluation in the Field of Civil Engineering
}

\author{
Igor Pšunder, Nadja Ferlan \\ University of Maribor, Faculty of Civil Engineering \\ Smetanova 17, 2000 Maribor, Slovenia
}

\begin{abstract}
The present article deals with use of capital budgeting methods in investment and project evaluation, with special emphasise on their use in the field of civil engineering. The research, presented in this article, was performed among project managers of Slovene companies. Their personal opinions about the use of capital budgeting methods and knowledge of their faults were studied during the research. Discounted cash flow methods were investigated, as well as single-period. During analysis of the results the situation in the field of civil engineering was treated separately and compared with other technical and non-technical sciences. Research showed that those experts dealing with investment evaluation who have a degree in the field of civil engineering use capital budgeting methods for investment evaluation less often than experts from other technical sciences, economics, and similar sciences. However, civil engineers are more familiar with the flaws in capital budgeting methods. More than $80 \%$ of civil engineers know the faults of the payback period method's disregard of payment expiration, but at the same time, only half of them know about the multiple internal rate of return, which is the most common fault of this method.
\end{abstract}

Keywords: civil engineering, single-period methods, discounted cash flow methods

\section{INTRODUCTION}

Research carried out at the end of the last century shows that, the use of discounted cash flow methods for investment and project evaluations has increased over the previous few decades. Among these methods, the internal rate of return method (IRR) and the net present value method (NPV) were the most common. Klammer and Walker ${ }^{[1]}$ stated that, in the USA "the use of discounting grew from $19 \%$ in 1960 to $57 \%$ in 1970", and their research established that the use of discounting in 1980 grew to $75 \%$ in those projects dealing with the expansion of existing capacities. Similar conclusions for the UK were drawn by $\mathrm{Pike}^{[2]}$, who established that the use of either the internal rate of return or net present value methods in large UK companies grew from $58 \%$ to $84 \%$ between 1975 and 1986. The aforementioned research raised questions about the use of capital budgeting methods in Slovenia. Special stress was placed on experts with education in civil engineering and companies who deal in this field of engineering.

Flaws in discounting cash flow methods: Numerous authors point out a lack of understanding regarding capital budgeting methods; Lumby and Jones ${ }^{[3]}$ focus mainly on flaws in the internal rate of return method, resulting from its polynomial foundation:

- on multiple internal rate of return,

- on non-existent internal rate of return, and

- in connection with the net present value method, also a non-existent positive net present value along with uniform internal rate of return.

All these faults are, if they appear, expressed in false or, at least, in inexact results (indications). Mauboussin $^{[4]}$ stresses faults which result from inadequate incoming data used by analysts for investment evaluations, such as forecast horizon anticipation being too short, or inadequate capital costs. Since these faults exceed the scope of our research, we haven't dealt with them in detail.

Flaws in single-period methods: Besides discounting cash flow methods, our research included methods of accounting rate of return and payback period. False interpretation of results can also appear with these methods. The biggest flaw regarding single-period methods is that they do not consider the time-value of the money. This fact can not be overseen, especially not in construction projects, which as a rule are of very long duration.

Corresponding Author: $\quad$ Igor Pšunder, University of Maribor, Faculty of Civil Engineering 17, Smetanova 17, Postal Code: SI-2000 Maribor, Slovenia, Tel: + 38622294 300, Fax: + 38622524179 
The most commonly used single period method is payback period. Puxty and Dodds ${ }^{[5]}$ see the additional problem of this method in the fact, that "it ignores all inflows after the payback period". It is also worth mentioning that this method does not allow adjustments for risks of particular project.

\section{MATERIALS AND METHODS}

Research framework: The main goal of the research was to establish the level of knowledge and use of capital budgeting methods among project managers in Slovenia. We compared knowledge and usage of these methods by civil engineers with that for the same methods among other technical engineers (mechanical and electrical) and also with those in natural, mathematical and other sciences.

Sample and data gathering: We gathered data using the questionnaire method. The sample included 44 companies covering all the Slovene regions. $13.64 \%$ of people involved in the research had education in the field of civil engineering; $15.91 \%$ worked in companies whose main activity is civil engineering. Half of the people with education in civil engineering worked in companies whose main activity is civil engineering; the rest worked in education or in financial agencies, agencies which deal with real estate or business services.

Among the respondents to the questionnaire, 18.18 $\%$ had education in the field of mechanical engineering, $20.45 \%$ in electrical engineering, and $36.4 \%$ were experts in economics or social science. Around onetenth of the questionnaire respondents had education in other fields (mathematics, chemistry, and geodesy). Over $34 \%$ of the respondents had a PhD or an MSc degree, almost $39 \%$ a university degree, more than 20 $\%$ a college degree, and less than $3 \%$ had a secondaryschool diploma.

The questionnaire was composed in the form of an internet application. People answering the questionnaire were asked to submit it by e-mail. $11.7 \%$ of invited participants returned the questionnaires.

The questionnaire had three parts:

- the first part dealt with the personal data of the person answering the questionnaire (age, degree,position, field of activity, size of the company, etc.);

- the second part was composed of questions about respondents' opinions of their knowledge and frequency of its use in regard to:

- discounting cash flow methods; we focused on the net present value method, the internal rate of return method, the net present value index, and the modified internal rate of return method, and

○ single-period methods, from which we selected two (payback period, accounting rate of return);

- the third part of the questionnaire consisted of questions about the respondents' opinions of their own knowledge concerning flaws in investment project evaluation methods. From discounting cash flow methods, we focused on the internal rate of return method; and from the single-period methods, we focused on faults of the payback period method.

Data analysis:. We calculated the dependence of method and faults knowledge against individual variables. For the analysis of dependence, we used contingency indicators (elementary indicator $\chi^{2}$, Pearson's contingency coefficient and correction of contingency).

\section{RESULTS}

Use of discounting cash flow methods and knowledge of their flaws: Among discounting cash flow methods, the most commonly used method in Slovene companies is the net present value method (average use is about $70 \%$ ), while the least popular is use of the modified internal rate of return method (on average less than $30 \%$ ). We could also establish that civil engineers most often use the internal rate of return method $(66.67 \%)$. A comparison of the use of individual methods among experts from different sciences is shown in Table 1.

Extensive use of the internal rate of return method among experts with an education in civil engineering can be explained in terms of ease of comparing the method's results with alternative investments, since the result is expressed in a percentage (of rate of return). The frequency of use of the net present value method is explicable by the simplicity of its calculation and by the generally widespread use of this method on calculators and electronic spreadsheets.

The modified internal rate of return method is the least used among the methods studied in our research, 
Table 1: Use of discounting cash flow methods by field of education

\begin{tabular}{lcccc}
\hline Method & Civil engineering & $\begin{array}{c}\text { Other technical } \\
\text { sciences }\end{array}$ & $\begin{array}{c}\text { Mathematical } \\
\text { and natural } \\
\text { science }\end{array}$ & Other sciences \\
\hline Net present value method & $50.0 \%$ & $70.59 \%$ & $40.0 \%$ & $87.5 \%$ \\
\hline $\begin{array}{l}\text { Internal rate of return } \\
\text { method }\end{array}$ & $66.67 \%$ & $58.82 \%$ & $60.0 \%$ & $81.3 \%$ \\
\hline $\begin{array}{l}\text { Net present value index } \\
\text { method }\end{array}$ & $16.67 \%$ & $41.18 \%$ & $20.0 \%$ & $56.3 \%$ \\
$\begin{array}{l}\text { Modified internal rate of } \\
\text { return method }\end{array}$ & $50.0 \%$ & $35.29 \%$ & $0.00 \%$ & $43.8 \%$ \\
\hline
\end{tabular}

Table 2: Knowledge of flaws in the internal rate of return method by field of education

\begin{tabular}{|c|c|c|c|c|}
\hline Deformation or restriction & Civil engineering & $\begin{array}{l}\text { Other technical } \\
\text { sciences }\end{array}$ & $\begin{array}{l}\text { Mathematical and } \\
\text { natural sciences }\end{array}$ & Other \\
\hline $\begin{array}{l}\text { Cross indication of net present value and } \\
\text { internal rate of return }\end{array}$ & $50,00 \%$ & $29,41 \%$ & $0.0 \%$ & $43.8 \%$ \\
\hline Multiple internal rate of return & $50,00 \%$ & $35,29 \%$ & $0.0 \%$ & $18.8 \%$ \\
\hline $\begin{array}{l}\text { Deformation due to presumption that all } \\
\text { payments are reinvested according to the } \\
\text { rate of return identical to the internal one }\end{array}$ & $16,67 \%$ & $17,65 \%$ & $20.0 \%$ & $56.3 \%$ \\
\hline Other & $0,00 \%$ & $0,00 \%$ & $0.0 \%$ & $12.5 \%$ \\
\hline
\end{tabular}

Table 3: Use and knowledge of single-period methods according to the field of education

\begin{tabular}{lccc}
\hline Field of education degree & Use of methods & $\begin{array}{c}\text { Knowledge of } \\
\text { methods }\end{array}$ & $\begin{array}{c}\text { Unfamiliar with the } \\
\text { methods }\end{array}$ \\
\hline Civil engineering & $69,23 \%$ & $15,38 \%$ & $15,38 \%$ \\
\hline Other technical sciences & $71,43 \%$ & $14,29 \%$ & $14,29 \%$ \\
\hline Mathematical and natural science & $50.0 \%$ & $10.0 \%$ & $40.0 \%$ \\
\hline Other sciences & $81.8 \%$ & $18.2 \%$ & $0.0 \%$ \\
\hline
\end{tabular}

Table 4: Knowledge of faults in the payback period method by field of education

\begin{tabular}{|c|c|c|c|c|}
\hline Deformation or restriction & Civil engineering & $\begin{array}{l}\text { Other technical } \\
\text { sciences }\end{array}$ & $\begin{array}{l}\text { Mathematical and } \\
\text { natural sciences }\end{array}$ & Other sciences \\
\hline Due to disregard of payment expiration & $83,33 \%$ & $41,18 \%$ & $20,00 \%$ & $62,50 \%$ \\
\hline Due to disregard of payments after payback period & $50,00 \%$ & $29,41 \%$ & $20,00 \%$ & $50,00 \%$ \\
\hline Due to incapacity for risk adjustment & $66,67 \%$ & $41,18 \%$ & $40,00 \%$ & $56,25 \%$ \\
\hline $\begin{array}{l}\text { Due to consideration of fixed (stabilized) payment } \\
\text { during evaluation period }\end{array}$ & $16,67 \%$ & $17,65 \%$ & $0,00 \%$ & $18,75 \%$ \\
\hline Other & $0,00 \%$ & $5,88 \%$ & $0,00 \%$ & $0,00 \%$ \\
\hline
\end{tabular}

although this method avoids the deficiencies that occur with the internal rate of return method (e. g.: it avoids the presumption that all payments are reinvested at the same rate of return as the internal one). We can presume, that the less frequent use of this method occurs due its lower level of recognition (usually not a standard feature of financial calculators) and partly by the lengthy calculation procedure involved.

In establishing the level of knowledge about faults, we focused on the internal rate of return method, because the authors quoted at the beginning of this article ascribe most faults to this method. We 
established that, in Slovene companies, less than half $(43.2 \%)$ of experts (in all sciences) are familiar with multiple internal rate of return, and only $16 \%$ know the problem of conflicting results (possibility of conflicting

Research results show that, according to their opinions, $12.5 \%$ of experts with a degree in economics or social science do know about other faults of the internal rate of return method.

Use of single-period investment project evaluation methods and knowledge of their faults: Analysis showed that single-period methods are still very popular in Slovene companies. Results from the research on use of single-period methods according to the field of education show that more than $69 \%$ of respondents with a civil engineering education answered that the companies they work for use singleperiod methods to determine justification for and success of investments. These methods are also very common among experts in mechanical and electronic sciences, but also the majority (more than $80 \%$ ) of experts with economics or social education uses this method. Table 3 shows detailed results on the use of single-period investment project evaluation methods.

Among single-period methods, the most commonly used is the payback period method, with the average frequency of use a little over three-quarters. This method is especially frequently used among people with education in »other sciences « $(87.5 \%$ of experts in these sciences use this method). Among civil engineers the payback period method is - contrary to our expectations - less common, because just half of them use this method in their work.

In research, how much the experts knew about faults of the payback period method depending on their field of education, we concluded, that experts with education in civil engineering have above average knowledge of flaws in this method, especially of result deformation due to disregard of payment maturity,disregard of payments after the expiry of the payback period and due to an incapacity for risk adjustment. The only exception is knowledge about result deformation due to consideration of fixed (stabilized) payments during the evaluation period: only $16.67 \%$ of respondents with civil engineering education are familiar with this. Research results showing the knowledge of various deficiencies in the payback period method are shown in Table 4.

We need to stress the fact that, according to their opinions, $5.88 \%$ of experts with education in other sciences are also familiar with additional faults of single-period investment project evaluation methods.

\section{DISCUSSION}

According to the research results we can conclude that capital budgeting methods are well-known in Slovenia. They are also very well-known by experts in the field of civil engineering. Regardless of the field of indications) between the internal rate of return and net present value methods. Major differences occurred between experts regarding different profiles; Table 2 shows these differences in detail. education, single-period methods are still more popular than discounting cash flow methods. Although singleperiod methods among civil engineers are less common than in compared sciences, civil engineers are above average in awareness of these methods' faults (payback period method was analyzed). The research also shows that experts who have education in civil engineering also possess above average knowledge about deficiencies in discounted cash flow methods (internal rate of return method was analyzed). This leads to the conclusion that civil engineers in Slovenia receive an above-average education regarding capital budgeting methods, compared to other sciences. However, due to relatively rare research about the use and knowledge of faults in capital budgeting methods among civil engineers, it was impossible to perform a comparison with other countries in the region.

Despite their above-average familiarity with the drawbacks, only half of those respondents with an education in civil engineering are familiar with result deformation due to disregard of payment maturity in the payback period method and multiple internal rate of return at the internal rate of return method. Since all of the questioned civil engineers worked on projects, the stated numbers seem quite disappointing.

Economic changes in Slovenia over recent decades have also influenced the curricula of secondary schools and faculties, which now place more stress on investment projects and capital budgeting methods. Therefore, tracking down any changes in the use of capital budgeting methods, and knowledge about their "pitfalls" could be a basis for further research.

\section{REFERENCES}

1. Klammer T. P., M. C. Walker, 1984. The continuing increase in the use of sophisticated capital budgeting techniques. California Management Review, 27 (1), 137-48.

2. Pike R. H., 1988. An empirical study of the adoption of sophisticated capital budgeting practices and decision making effectiveness, Accounting and Business Research, 18 (72), $341-51$.

3. Lumby S., C. Jones, 1999. Investment appraisal \& Finacial Decisions, $6^{\text {th }}$ edition, International Thomson Business Press, London.

4. Mauboussin M. J., 2006. Common Errors in DCF Models, Legg Mason Capital Management [online]. Available: http://www.leggmason.com/funds/knowledge/mau boussin/CommonDCFErrors.pdf.

5. Puxty A. G., J. C. Dodds, 1991. Financial management: method and meaning, $2^{\text {nd }}$ edition, Ed. Wilson, R. M. S., Chapman \& Hall, London, pp. 125. 